Royal Institution, illustrated with all the resources at its command, were a sheer delight. Simple yet profound, the non-scientific hearer could gather $a_{0}$ clear mental picture of the subject discussed, while the professional man of science enjoying the apparently effortless artistry of the presentation usually found that, in addition, he had gained some quite new side-lights on a subject with which he had thought himself completely familiar.

J. A. Crowther.

NeARLy twenty years ago, as a young graduate, I joined the team of research workers at University College, London, who were inspired and led by Sir William Bragg. His was a charming personality and he was an ideal research professor. Keen on his own work, bubbling over with enthusiasm at each new discovery; just as interested in ours, yet never obtrusive, never impatient. We knew that he shared our joy at each idea proved correct, because he himself had such an astonishing intuition. He knew where to look for knowledge ; but although intuition showed him the way, he was never satisfied with less than the most complete proof that the knowledge attained was fundamentally sound. An admitted mistake found him sympathetically understanding; like Faraday, he never regarded time as wasted if it increased experience. Yet he could be stern on occasion: a young man who spoke slightingly of one whose lifetime had been spent in determining one physical constant really accurately was most surprised to receive a sharp rebuke. Such painstaking and unspectacular labour Sir William knew to be the very cornerstone of research.

Sir William attracted and welcomed to the labora. tories of the Royal Institution workers from all parts of the world, and most of them must remember with gratitude not only the opportunities for scientific research and discussion thus afforded but also, and perhaps not least, the delightful garden parties given at his country cottage at Chiddingfold. Those of us who are still working on the problems that enthralled him to the last, feel that we have lost not only a leader but also a personal friend.

Kathleen Lonsdale.

\title{
NEW FELLOWS OF THE ROYAL SOCIETY
}

The following were elected to the fellowship of the Royal Society on March 19 :

ProF. J. H. BURN professor of pharmacology, Oxford, formerly dean of the College of the Pharmaceutical Society; distinguished for his work in physiology and pharmacology and on the principles and methods of biological standardization.

Dr. F. M. Burnet, assistant director of the Walter and Eliza Hall Institute for Medical Research, Melbourne ; distinguished for his researches in bacteriology, especially on avian and mammalian viruses.

Dr. M. Drxon, lecturer in biochemistry, Cambridge ; distinguished for his work on tissue respiration and respiratory catalysis.

Prof. E. C. Dodns, M.V.O., professor of biochemistry, Middlesex Hospital Medical School ; distinguished for his investigations in biochemistry in relation to physiology and medicine and especially in the synthetic production of œstrogenic agents.

Mr. A. FAGE, principal scientific officer, Aerodynamies Department, National Physical Laboratory; distinguished for his contributions to the experimental study of aero- and hydro-dynamics, particularly in relation to turbulent flow.

Colonel N. H. FaIrley, A.A.M.C., consulting physician in tropical diseases, director of special research, Hospital for Tropical Diseases, London; distinguished for his researches in tropical medicine.

Mr. P. HaLL, university lecturer in mathematics, Cambridge ; distinguished for his contributions to pure mathematics, particularly in the theory of groups.

Prof. G. H. Henderson, professor of mathematical physics, Dalhousie University, Halifax, Nova Scotia; distinguished for his work in radioactivity and particularly in the investigation of pleochroic haloes.

Prof. T. P. Hilditch, professor of industrial chemistry, Liverpool ; distinguished for his work on the chemistry of natural fats.

PROF. E. HrNDLE, regius professor of zoology, Glasgow ; distinguished for his work in parasitology, and on the cytology of artificial parthenogenesis.
Dr. C. S. Hanes, senior scientific officer, Low Temperature Research Station, Cambridge; distinguished for his researches in botany and biochemistry, especially the first enzymatic synthesis of starch.

Prof. A. Holmes, professor of geology, Durham ; distinguished for his work in petrology and the applications of radioactivity to geological problems.

Prof. D. M. NEwITT, assistant professor of chemical technology, Imperial College, London; distinguished for his work on high-pressure technology and for his researches on combustion.

Dr.C.C.Paterson, O.B.E., director of the Research Laboratories, General Electric Company, Wembley ; distinguished for his work in promoting physical and industrial research.

Dr. J. K. Roberts, assistant director of research, Colloid Science Laboratory, Cambridge; distinguished for his investigations by physical methods on adsorption and other surface phenomena of importance in catalysis.

Dr. H. W. B. Skinner, Wills research fellow and lecturer in spectroscopy, Bristol; distinguished for his work on the X-ray spectroscopy of the solid state, leading to results of importance in the theory of the structure of metals.

Prof. D. ThODAY, professor of botany, Bangor ; distinguished for his researches in plant physiology, particularly those dealing with photosynthesis, causal anatomy and the water relations of plants.

Prof. A. R. Todd, professor of chemistry, University of Manchester; distinguished for his researches in organic chemistry, notably the synthesis of vitamin $B_{1}$ and other natural compounds of physiological importance.

Prof. A. E. Trueman, professor of geology, Glasgow ; distinguished for his work in palæontology, particularly on molluscan faunas of the coal measures.

Mr. A. H. Wilson, university lecturer in mathematics, Cambridge; distinguished for his contributions to the electronic theory of solids and for his work on the properties of metals. 